\title{
Frog Spawn, is cancer to blame: A case report of Lympangioma circumscriptum
}

Jawaher Aljalahma, MD, Fatima Khamdan MD, Khalid Bin Thani MD*

Salmaniya Medical Complex, Manama, Kingdom of Bahrain

*Corresponding Author: Khalid Bin Thani MD, Salmaniya Medical Complex, Manama, Kingdom of Bahrain

Received date: 09 August 2021; Accepted date: 14 August 2021; Published date: 18 August 2021

Citation: Aljalahma J, Khamdan F, Thani KB (2021) Frog Spawn, is cancer to blame: A case report of Lympangioma circumscriptum. J Med

Case Rep Case Series 2(8): https://doi.org/10.38207/JMCRCS/2021/0208125

Copyright: (9) 2021 Khalid Bin Thani MD. This is an open-access article distributed under the terms of the Creative Commons Attribution License, which permits unrestricted use, distribution, and reproduction in any medium, provided the original author and source are credited.

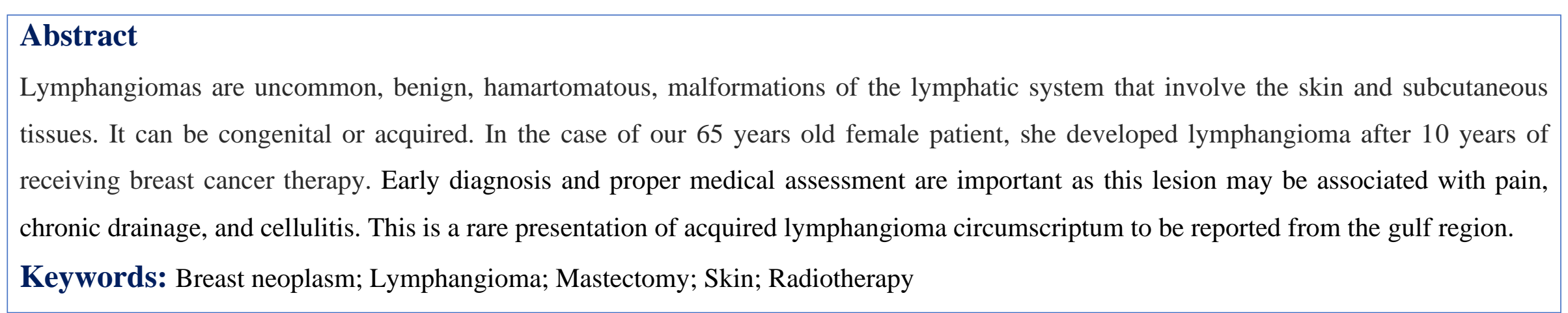

\section{Case Report}

A 65-year-old female known to have diabetes mellitus, hypertension, dyslipidemia and ischemic heart disease. The patient was in a good state of health till 2006 when she was diagnosed with breast cancer. Accordingly, the patient underwent left breast lumpectomy followed by chemotherapy and radiotherapy. After 10 years of completing her treatment, she presented again to the dermatology clinic with skin

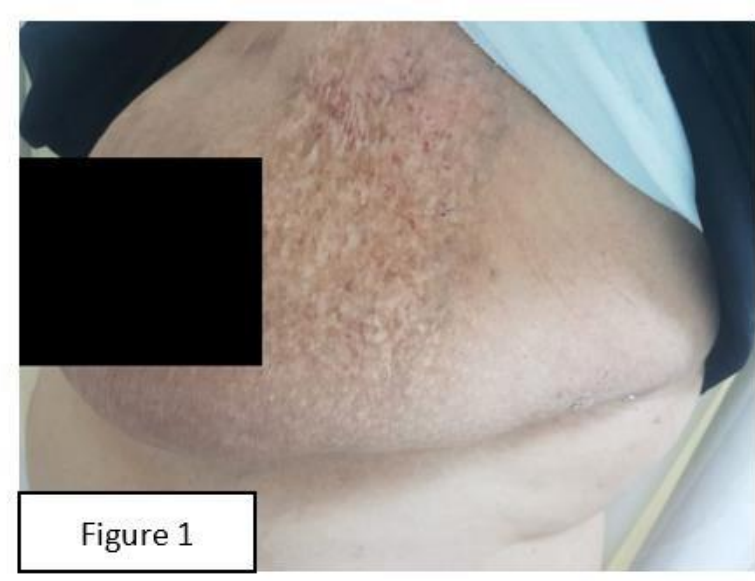

lesion in the same affected breast. The patient noticed it incidentally and her dermatological examination revealed chronic radiodermatitis of left breast (Figure 1) with obvious multiple, approximately 2 to 4 $\mathrm{mm}$ in size, skin colored, papulovesicles in the lateral side of left breast (Figure 2).

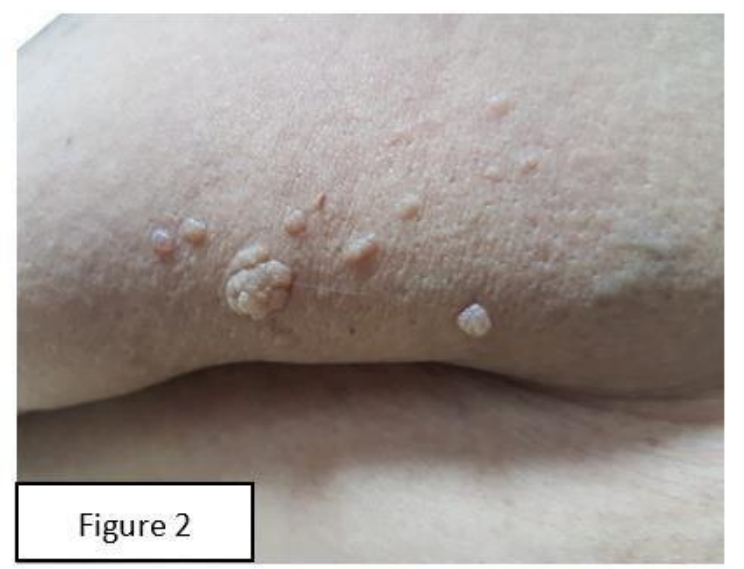

Figure 1: The left breast showing chronic radiodermatitis.

Figure 2: Left breast lateral side showing multiple skin colored papulovesicles

Our clinical suspicion was lymphangioma circumscriptum, However, cutaneous metastasis and angiosarcoma were considered. Skin biopsy was done. Histological examination revealed multiple dilated lymphatic vessels in superficial papillary dermis with flatted

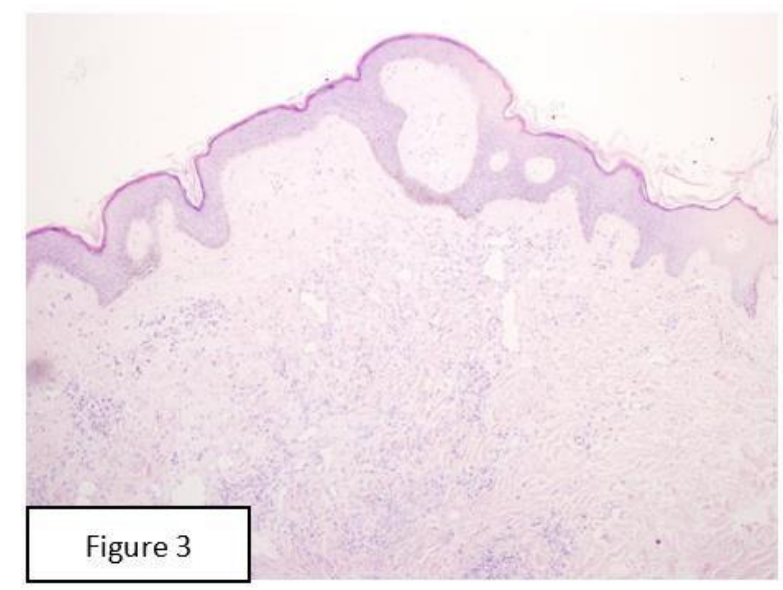

Figure 3: Histology slide of the lesion showing multiple dilated lymphatic vessels in superficial papillary dermis with flatted endothelial lining.

Figure 4: The immunohistochemistry slide with podoplanin immunostain, delineating the lymphatic endothelium.

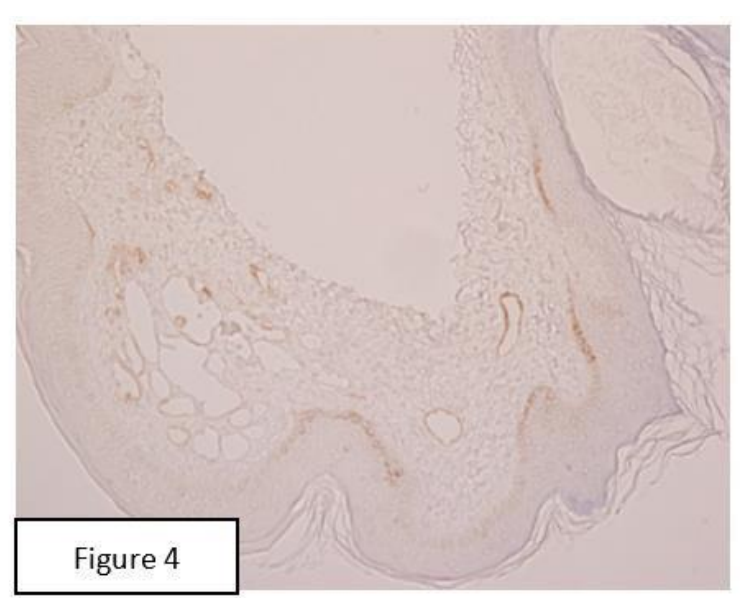

endothelial lining (Figure 3). Immunohistochemistry with podoplanin, which is specific for lymphatic endothelium, was positive (Figure 4). All suggestive of lymphangioma circumscriptum. 


\section{Discussion}

Vascular anomalies are classified into vascular tumors and vascular malformations according to the cellular turnover, histology and clinical findings [1]. Malformations may be seen in different vascular elements, such as lymphatic, capillaries or venous endothelium. Lymphangiomas are rare, benign malformation of the lymphatic system. They are analogous to hemangiomas, as they are formed by widely dilated lymphatic spaces, covered by endothelial cells, and separated by connective tissue stroma, associated with lymphoid aggregates [2]. There are 2 forms of lymphangioma, congenital and acquired. Congenital type is the most common form and represents 6 $\%$ of all benign lesions in children [3]. on the other hand, acquired lymphangioma is uncommon and results after external damage caused to previously normal lymphatics, leading to obstruction of local lymphatic drainage. First acquired lymphangioma reported was in 1956 by Plotnick and Richfield and they described a late squeal for radical mastectomy. Plotinck and Richfeild named the dilated lymphatic vessel as lymphangioiectasis [4]. It has been reported as clinically and histologically indistinguishable from congenital lymphangioma circumscriptum and is often reported in the literature as lymphangioma circumscriptum or acquired lymphangiomas [5] Acquired lymphangioma circuscuptum is micocystic lymphatic malformation. It has been associated with treatment for preceding malignant neoplasm e.g., breast and cervix and is often coexistent with lymphedema $[6,7,8]$, myxoid chondrosarcoma, bronchial carcinoid [9,10], and vulval tumors [11]

It can arise as a consequence of surgery, radiotherapy, chemotherapy alone or combination treatment. Chiyomaru et al did a retrospective series of 73 Japanese patients and reported that acquired lymphangioma risk is higher with combination therapy. In addition, he concluded that mean time for the development of lymphangioma circumscriptum is 5.8, 11.8 and 12.2 years for patient receiving combination of therapy, irradiation and chemotherapy, respectively [12]

Lymphanioma circumscriptum is characterized by persistent, multiple clusters of translucent vesicles that usually contain clear

\section{Conflict of interest: None}

\section{References}

1. Yarmand F, Seyyedmajidi M, Shirzad A, Foroughi R, Bakhshian A (2016) Lymphangiohemangioma of buccal mucosa: Report of a rare case. J Oral Maxillofac Surg Med Pathol. 28(4): 358-61

2. Kumar V, Abbas AK, Fausto N, Aster JA (2010) Robbins e Cotran: Bases Patológicas das Doenças. 8. ed. Rio de Janeiro: Elsevier.

3. Orvidas LJ, Kasperbauer JL (2000) Pediatric lymphangiomas of the head and neck. Ann Otol Rhinol Laryngol. 109(4): 411-21. lymph fluid with normal appearing skin between the lesions, which resemble frog spawn [13]. These vesicles represent superficial saccular dilations from underlying lymphatic vessels that occupy the papilla and push upward against the overlying epidermis. Each skin lesion may range from a minute vesicle to a small bulla-sized lesion. it can be clear or vary from pink to dark red because of hemangiolymphatic connections [14]. On histological examination will reveal dilated lymph vessels lined single layer of endothelial cells. These dilated lymph vessels usually found in papillary dermis. Immunohistochemical staining using podophlanin should be done to confirm the diagnosis. These histological findings of our case were consistent with these findings.

Complications of lymphangioa circumscriptum starts when the vesicles rupture. It will be a portal for entry of infection causing recurrent cellulitis and pain $[\mathbf{1 5 , 1 6 ]}$. While reviewing the literature, only one case has been reported of squamous cell carcinoma arising from congenital lymphangioma circumscriptim [17]

Prevention of superinfection when vesicles rupture is important. Daily cleansing with topical antibacterial agent and applying mupirocin antibacterial ointment. Lymphangioma circumscriptum is cosmetically undesirable, surgical intervensions may be considered such as electrodesiccation, laser therapy, sclerotherapy, cryotherapy, and surgical excision [5,6]. Gianelli and Rockley found electrodessication superior to the other treatment modalities [6]. Each therapeutic option is effective, but recurrences are common and may be complicated by scarring.

\section{Conclusion}

acquired lymphangioma circumscuptum is considered late sequel for iatrogenic treatments done for a known cancer. despite the rarity of lymphangioma circumscruptum, it is important to diagnose it to undergo the medical versus surgical treatment needed to prevent superinfection and recurrent cellulitis.

4. Plotinick H, Richfield D (1956) Tuberous lymphangiectatic varices secondary to radical mastectomy. AMA Arch Derm. 74(5): 466-8.

5. Celis, AV, Gaughf CN, Sangueza OP, Gourdin FW (1999) Acquired lymphangiectasis. South Med J. 92(1): 69-72.

6. Giannelli V, Rockley PF (1996) Acquired lymphangiectasis following mastectomy and radiation therapy--report of a case and review of the literature. Cutis. 58(4): 276-8. 
7. Kaya TI, Kokturk A, Polat A, Tursen U, Ikizoglu G (2001) A case of cutaneous lymphangiectasis secondary to breast cancer treatment. Int J Dermatol. 40(12): 760-1.

8. Mallett, RB, Curley, GK, Mortimer, PS (1992) Acquired lymphangioma: report of four cases and a discussion of the pathogenesis. Br J Dermatol. 126(4): 380-2.

9. Moon SE, Youn JI, Lee YS (1993) Acquired cutaneous lymphangiectasia. Br J Dermatol. 129(2): 193-5.

10. Ziv R, Schewach-Miller M, Trau U (1988) Lymphangiectasia. A complication of thoracotomy for bronchial carcinoid. Int $\mathrm{J}$ Dermatol. 27(2): 123.

11. Schwab RA, McCollugh ML (2001) Acquired vulvar lymphangiomas: a sequela of radiation therapy. Cutis. 67(3): 23940.

12. Chiyomaru K, Nishigori C (2009) Acquired lymphangiectasia associated with treatment for preceding malignant neoplasm: a retrospective series of 73 Japanese patients. Arch Dermatol. 145(7): 841-2.

13. Patel GA, Siperstein RD, Ragi G, Schwartz RA (2009) Zosteriform lymphangioma circumscriptum. Acta Dermatovenerol Alp Panonica Adriat. 18(4): 179-182.

14. Kolay SK, Parwani R, Wanjari S, Singhal P (2018) Oral lymphangiomas-clinical and histopathological relations: An immunohistochemically analyzed case series of varied clinical presentations. J Oral Maxillofac Pathol. 2018 Jan. 22(Suppl 1): S108-S111

15. Bhattacharyya NC, Yadav K, Mitra SK, Pathak IC (1981) Lymphangiomas in children. Aust N Z J Surg. 51(3): 296-300.

16. Peachey RD, Lim CC, Whimster IW (1970) Lymphangioma of skin. A review of 65 cases. Br J Dermatol. 83(5): 519-27.

17. Wilson GR, Cox NH, McLean NR, Scott D (1993) Squamous cell carcinoma arising within congenital lymphangioma circumscriptum. Br J Dermatol. 129(3): 337-9. 